University of Nebraska - Lincoln

DigitalCommons@University of Nebraska - Lincoln

Agronomy \& Horticulture -- Faculty Publications

Agronomy and Horticulture Department

January 2008

\title{
When Does Nitrate Become a Risk for Humans?
}

\author{
David S. Powlson \\ Rothamsted Research \\ Tom M. Addiscott \\ Rothamsted Research \\ Nigel Benjamin \\ Derriford Hospital \\ Kenneth G. Cassman \\ University of Nebraska-Lincoln, kcassman1@unl.edu \\ Theo M. de Kok \\ University Maastricht
}

See next page for additional authors

Follow this and additional works at: https://digitalcommons.unl.edu/agronomyfacpub

Part of the Plant Sciences Commons

Powlson, David S.; Addiscott, Tom M.; Benjamin, Nigel; Cassman, Kenneth G.; de Kok, Theo M.; van Grinsven, Hans; L'hirondel, Jean-Louis; Avery, Alex A.; and Van Kessel, Chris, "When Does Nitrate Become a Risk for Humans?" (2008). Agronomy \& Horticulture -- Faculty Publications. 102.

https://digitalcommons.unl.edu/agronomyfacpub/102

This Article is brought to you for free and open access by the Agronomy and Horticulture Department at DigitalCommons@University of Nebraska - Lincoln. It has been accepted for inclusion in Agronomy \& Horticulture -Faculty Publications by an authorized administrator of DigitalCommons@University of Nebraska - Lincoln. 


\section{Authors}

David S. Powlson, Tom M. Addiscott, Nigel Benjamin, Kenneth G. Cassman, Theo M. de Kok, Hans van Grinsven, Jean-Louis L'hirondel, Alex A. Avery, and Chris Van Kessel 


\section{When Does Nitrate Become a Risk for Humans?}

\author{
David S. Powlson and Tom M. Addiscott Rothamsted Research \\ Nigel Benjamin Derriford Hospital \\ Ken G. Cassman University of Nebraska \\ Theo M. de Kok University Maastricht \\ Hans van Grinsven Netherlands Environmental Assessment Agency \\ Jean-Louis L'hirondel Centre Hospitalier Universitaire de Caen \\ Alex A. Avery Hudson Institute \\ Chris van Kessel* University of California-Davis
}

Is nitrate harmful to humans? Are the current limits for nitrate concentration in drinking water justified by science? There is substantial disagreement among scientists over the interpretation of evidence on the issue. There are two main health issues: the linkage between nitrate and (i) infant methaemoglobinaemia, also known as blue baby syndrome, and (ii) cancers of the digestive tract. The evidence for nitrate as a cause of these serious diseases remains controversial. On one hand there is evidence that shows there is no clear association between nitrate in drinking water and the two main health issues with which it has been linked, and there is even evidence emerging of a possible benefit of nitrate in cardiovascular health. There is also evidence of nitrate intake giving protection against infections such as gastroenteritis. Some scientists suggest that there is sufficient evidence for increasing the permitted concentration of nitrate in drinking water without increasing risks to human health. However, subgroups within a population may be more susceptible than others to the adverse health effects of nitrate. Moreover, individuals with increased rates of endogenous formation of carcinogenic $\mathrm{N}$-nitroso compounds are likely to be susceptible to the development of cancers in the digestive system. Given the lack of consensus, there is an urgent need for a comprehensive, independent study to determine whether the current nitrate limit for drinking water is scientifically justified or whether it could safely be raised.

Copyright $\odot 2008$ by the American Society of Agronomy, Crop Science Society of America, and Soil Science Society of America. All rights reserved. No part of this periodical may be reproduced or transmitted in any form or by any means, electronic or mechanical, including photocopying, recording, or any information storage and retrieval system, without permission in writing from the publisher.

Published in J. Environ. Qual. 37:291-295 (2008).

doi:10.2134/jeq2007.0177

Received 10 Apr. 2007.

*Corresponding author (cvankessel@ucdavis.edu).

○ ASA, CSSA, SSSA

677 S. Segoe Rd., Madison, WI 53711 USA
Is nitrate harmful to humans? Are the current limits for nitrate concentration in drinking water justified by science? These questions were addressed at a symposium on "The Nitrogen Cycle and Human Health" held at the annual meeting of the Soil Science Society of America (SSSA). Although they sound like old questions, it became clear there is still substantial disagreement among scientists over the interpretation of evidence on the issue-disagreement that has lasted for more than 50 years.

This article is based on the discussion at the SSSA meeting and subsequent email exchanges between some of the participants. It does not present a consensus view because some of the authors hold strongly divergent views, drawing different conclusions from the same data. Instead, it is an attempt to summarize, to a wider audience, some of the main published information and to highlight current thinking and the points of contention. The article concludes with some proposals for research and action. Because of the divergent views among the authors, each author does not necessarily agree with every statement in the article.

\section{Present Regulatory Situation}

In many countries there are strict limits on the permissible concentration of nitrate in drinking water and in many surface waters. The limit is $50 \mathrm{mg}$ of nitrate $\mathrm{L}^{-1}$ in the EU and $44 \mathrm{mg}$ $\mathrm{L}^{-1}$ in the USA (equivalent to 11.3 and $10 \mathrm{mg}$ of nitrate- $\mathrm{N} \mathrm{L}^{-1}$, respectively). These limits are in accord with WHO recommendations established in 1970 and recently reviewed and reconfirmed (WHO, 2004). The limits were originally set on the basis of human health considerations, although environmental concerns, such as nutrient enrichment and eutrophication of surface waters, are now seen as being similarly relevant. It is the health

D.S. Powlson and T.M. Addiscott, Soil Science Dep., Rothamsted Research, Harpenden, Herts AL5 2JQ, United Kingdom; N. Benjamin, Derriford Hospital, Brest Rd, Derriford, Plymouth, PL6 5AA, United Kingdom; K.G. Cassman, Dep. of Agronomy and Horticulture, Univ. of Nebraska, Lincoln, NE, 68583 USA; T.M. de Kok, Dep. of Health Risk Analysis and Toxicology, University Maastricht, P.O. Box 616, 6200 MD the Netherlands; H. van Grinsven, Netherlands Environmental Assessment Agency, P.O. Box 303, 3720 AH Bilthoven, the Netherlands; J.-L. L'hirondel, Service de rhumatologie, Centre Hospitalier Universitaire de Caen, 14033 Caen Cedex, France; A.A. Avery, Center for Global Food Issues, Hudson Inst., PO Box 202, Churchville, VA 24421 USA; C. van Kessel, Dep. of Plant Sciences, Univ. of California, Davis, CA, 95616 USA. 
issues that are the main cause of disagreement; the contrasting views are set out in the following two sections.

\section{Nitrate and Health}

There are two main health issues: the linkage between nitrate and (i) infant methaemoglobinaemia, also known as blue baby syndrome, and (ii) cancers of the digestive tract. The evidence for nitrate as a cause of these serious diseases remains controversial and is considered below.

\section{An Over-Stated Problem?}

The link between nitrate and the occurrence of methaemoglobinaemia was based on studies conducted in the 1940s in the midwest of the USA. In part, these studies related the incidence of methaemoglobinaemia in babies to nitrate concentrations in rural well water used for making up formula milk replacement. Comly (1945), who first investigated what he called "well-water methaemoglobinaemia," found that the wells that provided water for bottle feeding infants contained bacteria as well as nitrate. He also noted that "In every one of the instances in which cyanosis (the clinical symptom of methaemoglobinaemia) developed in infants, the wells were situated near barnyards and pit privies." There was an absence of methaemoglobinaemia when formula milk replacements were made with tap water. Re-evaluation of these original studies indicate that cases of methaemoglobinaemia always occurred when wells were contaminated with human or animal excrement and that the well water contained appreciable numbers of bacteria and high concentrations of nitrate (Avery, 1999). This strongly suggests that methaemoglobinaemia, induced by well water, resulted from the presence of bacteria in the water rather than nitrate per se. A recent interpretation of these early studies is that gastroenteritis resulting from bacteria in the well water stimulated nitric oxide production in the gut and that this reacted with oxyhaemoglobin in blood, converting it into methaemoglobin (Addiscott, 2005).

The nearest equivalent to a present-day toxicological test of nitrate on infants was made by Cornblath and Hartmann (1948). These authors administered oral doses of 175 to 700 $\mathrm{mg}$ of nitrate per day to infants and older people. None of the doses to infants caused the proportion of heamoglobin converted to methaemoglobin to exceed $7.5 \%$, strongly suggesting that nitrate alone did not cause methaemoglobinaemia. Furthermore, Hegesh and Shiloah (1982) reported another common cause of infant methaemoglobinaemia: an increase in the endogenous production of nitric oxide due to infective enteritis. This strongly suggests that many early cases of infant methaemoglobinaemia attributed at that time to nitrate in well water were in fact caused by gastroenteritis. Many scientists now interpret the available data as evidence that the condition is caused by the presence of bacteria rather than nitrate (Addiscott, 2005; L'hirondel and L'hirondel, 2002). The report of the American Public Health Association (APHA, 1950) formed the main basis of the current recommended $50 \mathrm{mg} \mathrm{L}^{-1}$ nitrate limit, but even the authors of the report recognized that it was compromised by unsatisfactory data and methodological bias. For example, in many cases, samples of water from wells were only taken for nitrate analysis many months after the occurrence of infant methaemoglobinaemia.

About 50 epidemiological studies have been made since 1973 testing the link between nitrate and stomach cancer incidence and mortality in humans, including Forman et al. (1985) and National Academy of Sciences (1981). The Chief Medical Officer in Britain (Acheson, 1985), the Scientific Committee for Food in Europe (European Union, 1995), and the Subcommittee on Nitrate and Nitrite in Drinking Water in the USA (NRC, 1995) all concluded that no convincing link between nitrate and stomach cancer incidence and mortality had been established.

A study reported by Al-Dabbagh et al. (1986) compared incidence of cancers between workers in a factory manufacturing nitrate fertilizer (and exposed to a high intake of nitrate through dust) and workers in the locality with comparable jobs but without the exposure to nitrate. There was no significant difference in cancer incidence between the two groups.

Based on the above findings showing no clear association between nitrate in drinking water and the two main health issues with which it has been linked, some scientists suggest that there is now sufficient evidence for increasing the permitted concentration of nitrate in drinking water without increasing risks to human health (L'hirondel et al., 2006; Addiscott, 2005).

Space does not permit here to discuss other concerns expressed about dietary nitrate, such as risk to mother and fetus, genotoxicity, congenital malfunction, enlarged thryroid gland, early onset of hypertension, altered neurophysiological function, and increased incidence of diabetes. For differing views of other possible health concerns, see L'hirondel and L'hirondel (2002) and Ward et al. (2006).

Nitrate is made in the human body (Green et al., 1981), the rate of production being influenced by factors such as exercise (Allen et al., 2005). In recent years it has been shown that body cells produce nitric oxide from the amino acid L-arginine and that this production is vital to maintain normal blood circulation (Richardson et al., 2002) and protection from infection (Benjamin, 2000). Nitric oxide is rapidly oxidized to form nitrate, which is conserved by the kidneys and concentrated in the saliva. Nitrate can also be chemically reduced to nitric oxide in the stomach, where it can aid in the destruction of swallowed pathogens that can cause gastroenteritis.

Evidence is emerging of a possible benefit of nitrate in cardiovascular health. For example, the coronaries of rats provided water for 18 mo that contained sodium nitrate became thinner and more dilated that the coronaries of the rats in the control group (Shuval and Gruener, 1977). Nitrate levels in water showed a negative correlation coefficient with the standardized mortality ratio for all cardiovascular diseases (Pocock et al., 1980). In healthy young volunteers, a short-term increase in dietary nitrate reduced diastolic blood pressure (Larsen et al., 2006). Based on these data, one could hypothesize that nitrate might also play a role in the cardiovascular health benefit of vegetable consumption (many vegetables contain high concentrations of nitrate) (Lundberg et al., 2004). 


\section{The Need for Caution}

Although there is little doubt that normal physiological levels of nitric oxide play a functional role in vascular endothelial function and the defense against infections (Dykhuizen et al., 1996), chronic exposure to nitric oxide as a result of chronic inflammation has also been implicated, though not unequivocally identified, as a critical factor to explain the association between inflammation and cancer (Sawa and Oshima, 2006; Dincer et al., 2007; Kawanishi et al., 2006). Nitric oxide and $\mathrm{NO}$-synthase are known to be involved in cancer-related events (angiogenesis, apoptosis, cell cycle, invasion, and metastasis) and are linked to increased oxidative stress and DNA damage (Ying and Hofseth, 2007). Rather than nitrate, the presence of numerous classes of antioxidants is generally accepted as the explanation for the beneficial health effects of vegetable consumption (Nishino et al., 2005; Potter and Steinmetz, 1996).

A recent review of the literature suggests that certain subgroups within a population may be more susceptible than others to the adverse health effects of nitrate (Ward et al., 2005). Although there is evidence showing the carcinogenity of $\mathrm{N}$-nitroso compounds in animals, data obtained from studies that were focused on humans are not definitive, with the exception of the tobacco-specific nitrosamines (Grosse et al., 2006). The formation of N-nitroso compounds in the stomach has been connected with drinking water nitrate, and excretion of $\mathrm{N}$-nitroso compounds by humans has been associated with nitrate intake at the acceptable daily intake level through drinking water (Vermeer et al., 1998). The metabolism of nitrate and nitrite, the formation of $\mathrm{N}$-nitroso compounds, and the development of cancers in the digestive system are complex processes mediated by several factors. Individuals with increased rates of endogenous formation of carcinogenic $\mathrm{N}$-nitroso compounds are likely to be susceptible. Known factors altering susceptibility to the development of cancers in the digestive system are inflammatory bowel diseases, high red meat consumption, amine-rich diets, smoking, and dietary intake of inhibitors of endogenous nitrosation (e.g., polyphenols and vitamin C) (de Kok et al., 2005; De Roos et al., 2003; Vermeer et al., 1998). In 1995, when the Subcommittee on Nitrate and Nitrate in Drinking Water reported that the evidence to link nitrate to gastric cancer was rather weak (NRC, 1995), the stomach was still thought to be the most relevant site for endogenous nitrosation. Previous studies, such as those reviewed in the NRC (1995) report, which found no link between nitrate and stomach cancer, concentrated on the formation of nitrosamines in the stomach. Recent work indicates that larger amounts of $\mathrm{N}$-nitroso compounds can be formed in the large intestine (Cross et al., 2003; De Kok et al., 2005).

Some scientists argue that there are plausible explanations for the apparent contradictive absence of adverse health effects of nitrate from dietary sources (Van Grinsven et al., 2006; Ward et al., 2006). Individuals with increased rates of endogenous formation of carcinogenic $\mathrm{N}$-nitroso compounds are more likely to be at risk, and such susceptible subpopulations should be taken into account when trying to make a risk-benefit analysis for the intake of nitrate. In view of these complex dose-response mechanisms, it can be argued that it is not surprising that ecological and cohort studies (e.g., Van Loon et al., 1998) in general do not provide statistically significant evidence for an association between nitrate intake and gastric, colon, or rectum cancers. The experimental design of most of these studies may not have been adequate to allow for the determination of such a relationship.

Population studies have the problem that factors influencing health tend to be confounded with each other. This necessitates molecular epidemiological studies aimed at improving methods for assessing exposure in susceptible subgroups. This approach requires the development of biomarkers that enable the quantification of individual levels of endogenous nitrosation and $\mathrm{N}$-nitroso compounds exposure and methods for accurate quantification of exposure-mediating factors.

\section{Nitrate, Food Security, and the Environment}

It is beyond dispute that levels of nitrate and other N-containing species have increased in many parts of the ecosystem due to increased use of fertilizers and combustion of fossil fuels. At present, 2 to $3 \%$ of the population in USA and the $\mathrm{EU}$ are potentially exposed to public or private drinking water exceeding the present WHO (and USA and EU) standard for nitrate in drinking water. The proportion of the exposed population in the emerging and developing economies is probably larger and increasing (Van Grinsven et al., 2006).

The environmental impacts of reactive $\mathrm{N}$ compounds are serious, and continued research on agricultural systems is essential to devise management practices that decrease losses and improve the utilization efficiency of $\mathrm{N}$ throughout the food chain. At the same time, the central role of $\mathrm{N}$ in world agriculture must be considered. Agriculture without $\mathrm{N}$ fertilizer is not an option if the 6.5 billion people currently in the world and the 9 billion expected by 2050 are to be fed (Cassman et al., 2003). Losses of reactive $\mathrm{N}$ compounds to the environment are not restricted to fertilizers: losses from manures and the residues from legumes can also be large (Addiscott, 2005). Research indicates that simply mandating a reduction in $\mathrm{N}$ fertilizer application rates does not automatically reduce $\mathrm{N}$ losses because there is typically a poor relationship between the amount of $\mathrm{N}$ fertilizer applied by farmers and the $\mathrm{N}$ uptake efficiency by the crops (Cassman et al., 2002; Goulding et al., 2000). Instead, an integrated systems management approach is needed to better match the amount and timing of $\mathrm{N}$ fertilizer application to the actual crop $\mathrm{N}$ demand in time and space. Such an approach would lead to decreased losses of reactive $\mathrm{N}$ to the environment without decreasing crop yields. Many of the potential conflicts between the agricultural need for $\mathrm{N}$ and the environmental problems caused by too much in the wrong place are being studied within the International Nitrogen Initiative (INI; http://initrogen.org/), a networking activity sponsored by several international bodies.

The adverse environmental impact of reactive $\mathrm{N}$ species (i.e., all $\mathrm{N}$-containing molecules other than the relatively inert $\mathrm{N}_{2}$ gas that comprises $78 \%$ of the atmosphere) deserves attention. Some of these molecules, such as nitrogen oxides, come from combustion of fossil fuels in automobiles and power plants. Agriculture, however, is the dominant source through the cultivation of $\mathrm{N}_{2}$-fixing crops and the manufacture and use of $\mathrm{N}$ fertilizers (Turner and Rabalais, 2003). Both have increased greatly over the 
last few decades, and the trend is set to continue (Galloway et al., 2003 ; 2004). The subsequent $\mathrm{N}$ enrichment causes changes to terrestrial and aquatic ecosystems and to the environmental services they provide. Examples include nitrate runoff to rivers causing excessive growth of algae and associated anoxia in coastal and estuarine waters (James et al., 2005; Rabalais et al., 2001) and deposition of $\mathrm{N}$-containing species from the atmosphere causing acidification of soils and waters and $\mathrm{N}$ enrichment to forests and grassland savannahs (Goulding et al., 1998). All of these impacts can radically change the diversity and numbers of plant and animal species in these ecosystems. Other impacts almost certainly have indirect health effects, such as nitrous oxide production, which contributes to the greenhouse effect and the destruction of the ozone layer, thereby allowing additional UV radiation to penetrate to ground level with the associated implications for the prevalence of skin cancers.

Losses of nitrate to drinking water resources are also associated with leaky sewage systems. Leaky sewage systems need to be improved for general hygiene considerations. This need is especially important in developing countries and poor rural areas that do not have well developed sewage and waste disposal infrastructure.

\section{Returning Question}

In considering the management of nitrogen in agriculture and its fate in the wider environment, the debate keeps returning to the original question: "Is nitrate in drinking water really a threat to health?" Interpretations of the evidence remain very different (L'hirondel et al., 2006; Ward et al., 2006). The answer has a significant economic impact. The current limits established for ground and surface waters require considerable changes in practice by water suppliers and farmers in many parts of the world, and these changes have associated costs. If nitrate in drinking water is not a hazard to health, could the current limit be relaxed, perhaps to 100 $\mathrm{mg} \mathrm{L}^{-1}$ ? The relaxation could be restricted to situations where the predominant drainage is to groundwater. Such a change would allow environmental considerations to take precedence in the case of surface waters where eutrophication is the main risk, and $\mathrm{N}$ limits could be set to avoid damage to ecosystem structure and function. Phosphate is often the main factor limiting algal growth and eutrophication in rivers and freshwater lakes, so a change in the nitrate limit would focus attention on phosphate and its management - correctly so in the view of many environmental scientists (Sharpley et al., 1994). It is possible that a limitation on phosphate might lead to even lower nitrate limits in some freshwater aquatic environments to restore the diversity of submerged plant life (James et al., 2005). It could be argued that setting different limits, determined by health or environmental considerations as appropriate, is a logical response to the scientific evidence.

Given the criticisms of the scientific foundation of present drinking water standards and the associated cost-benefits of prevention or removal of nitrate in drinking water, we propose the need to consider the following issues in discussing an adjustment of the nitrate standards for drinking water:

- Nitrogen intake by humans has increased via drinking water and eating food such as vegetables.
- There is circumstantial and often indirect evidence of the enhanced risk of cancers of the digestive system after an increase in the concentration of nitrate in drinking water. There is an urgent need to synthesize existing data and understanding, or to carry out additional research if necessary, to reach clear and widely accepted conclusions on the magnitude of the risk. This will require greater collaboration between scientists who hold opposing views over the interpretation of currently available data. The possibility that subgroups within the population respond differently requires quantification and critical examination.

- Nitrogen oxides have a functional role in normal human physiology, but they are also involved in the induction of oxidative stress and DNA damage. The challenge is to quantify and evaluate these risks and benefits of nitric oxide exposure in relation to the intake of nitrate in drinking water. If humans have a mechanism to combat infectious disease with nitric oxide, produced from nitrate consumed in drinking water and food, what are the long-term effects of the nitric oxide benefits compared with the potential negative health effects from higher intake of nitrate?

- If the evaluation of potential adverse health effects from chronic exposure to nitrate levels in drinking water above $50 \mathrm{mg} \mathrm{L}^{-1}$ demonstrates that these adverse effects can be considered minor compared with other issues of health loss associated with air pollution or life style, would the removal of nitrate from drinking water to meet the current allowable concentration standards be cost-efficient relative to other potential investments in health improvement?

Although science may not provide society with unequivocal conclusions about the relationship between drinking water nitrate and health over the short term, there are good reasons to further explore the issue (Ward et al., 2005). Unfortunately, it remains difficult to predict the health risks associated with chronic nitrate consumption from water that exceeds the current $\mathrm{WHO}$ drinking water standard. One complication is the endogenous production of nitrate, which makes it more difficult than previously realized to relate health to nitrate intake in water or food.

Practical management strategies to overcome inefficient use of nitrogen by crops and to minimize losses of nitrate and other $\mathrm{N}$-containing compounds to the environment have to be developed for agricultural systems worldwide.

Given the lack of consensus, there is an urgent need for a comprehensive, independent study to determine whether the current nitrate limit for drinking water is scientifically justified or whether it could safely be raised. Meta-analyses are valuable tools for generating conclusions about specific chronic health effects (e.g., stomach cancer, colon cancer, bladder cancer, specific reproductive outcomes). Unfortunately, the number of suitable studies for any particular health effect is likely too small to be detected by meta-analyses (Van Grinsven et al., 2006). Empirical studies focused on susceptible subgroups, development of biomarkers for demonstration of endogenous nitrosation, and methods for 
accurate quantification of mediating factors may provide part of the answers. Moreover, there is also a separate need for determining water quality standards for environmental integrity of aquatic ecosystems. It is time to end $50 \mathrm{yr}$ of uncertainty and move forward in a timely fashion toward science-based standards.

\section{References}

Acheson, E.D. 1985. Nitrate in drinking water. HMSO, London, UK.

Addiscott, T.M. 2005. Nitrate, agriculture, and environment. CABI Publ., Wallingford, Oxfordshire, UK.

Al-Dabbagh, S., D. Forman, D. Bryson, I. Stratton, and R. Doll. 1986. Mortality of nitrate fertilizer workers. Brit. J. Industr. Med. 43:507-515.

Allen, J.D., F.R. Cobb, and A.J. Gow. 2005. Regional and whole-body markers of nitric oxide production following hyperemic stimuli. Free Radical Biol. Med. 38:1164-1169.

APHA. 1950. Committee on water supply: Nitrate in potable waters and methaemoglobinaemia. Am. Public Health Assoc. Yearb. 40:110-115.

Avery, A.A. 1999. Infantile methaemoglobinaemia: Reexamining the role of drinking water nitrates. Environ. Health Perspect. 107:583-586.

Benjamin, N. 2000. Nitrates in the human diet-Good or bad? Ann. Zootechnol. 49:207-216.

Cassman, K.G., A.D. Dobermann, and D.T. Walters. 2002. Agroecosystems, Nuse efficiency, and N management. Ambio 31:132-140.

Cassman, K.G., A.D. Dobermann, D.T. Walters, and H. Yang. 2003. Meeting cereal demand while protecting natural resources and improving environmental quality. Ann. Rev. Environ. Resour. 28:315-358.

Comly, H.H. 1945. Cyanosis in infants caused by nitrates in well water. JAMA 129:112-116.

Cornblath, M., and A.F. Hartmann. 1948. Methaemoglobinaemia in young infants. J. Pediatr. 33:421-425.

Cross, A.J., J.R. Pollock, and S.A. Bingham. 2003. Heam, not protein or inorganic iron, is responsible for endogenous intestinal $\mathrm{n}$-nitrosation arising from red meat. Cancer Res. 63:2358-2360.

de Kok, T.M.C.M., L.G.J.B. Engels, E.J. Moonen, and J.C.S. Kleinjans. 2005. Inflammatory bowel disease stimulates formation of carcinogenic $\mathrm{N}$-nitroso compounds. Gut 54:731.

De Roos, A.J., M.H. Ward, C.F. Lynch, and K.P. Cantor. 2003. Nitrate in public water systems and the risk of colon and rectum cancers. Epidemiology 14:640-649.

Dincer, Y., Y. Erzin, S. Himmetoglu, K. Nur Gunes, K. Bal, and T. Akcay. 2007. Oxidative DNA damage and antioxidant activity in patients with inflammatory bowel disease. Dig. Dis. Sci., DOI 10.10007/s1062000609386-8.

Dykhuizen, R.S., A. Fraser, C. Duncan, C.C. Smith, M. Golden, B. Benjamin, and C. Leifert. 1996. Antimicrobial effect of acidified nitrite on gut pathogens: Importance of dietary nitrate in host defense. Antimicrob. Agents Chemother. 40:1422-1425.

European Union. 1995. European Commission Directorate-General III Industry. Scientific Committee for Food. Opinion on Nitrate and Nitrite. Annex 4 to Document III/5611/95.

Forman, D., A. Al-Dabbagh, and R. Doll. 1985. Nitrate, nitrite, and gastric cancer in Great Britain. Nature 313:620-625.

Galloway, J.N., J.D. Aber, J.W. Erisman, S.P. Seitzinger, R.W. Howarth, E.B. Cowling, and B.J. Cosby. 2003. The nitrogen cascade. Bioscience 53:1-16.

Galloway, J.N., F.J. Dentener, D.G. Capone, E.W. Boyer, R.W. Howarth, S.P. Seitzinger, G.P. Asier, C. Cleveland, P. Green, E. Holland, D.M. Karl, A.F. Michaels, J.H. Porter, A. Townsend, and C. Vorosmary. 2004. Nitrogen cycles: Past, present, and future. Biogeochemistry 70:153-226.

Goulding, K.W.T., N.J. Bailey, N.J. Bradbury, P. Hargreaves, M. Howe, D.V. Murphy, P.R. Poulton, and T.W. Willison. 1998. Nitrogen deposition and its contribution to nitrogen cycling and associated processes. New Phytol. 139:49-58.

Goulding, K.W.T., P.R. Poulton, C.P. Webster, and M.T. Howe. 2000. Nitrogen leaching from the Broadbalk Wheat Experiment, Rothamsted, UK, as influenced by fertilizer and manure inputs and weather. Soil Use Manage. 16:244-250.

Green, L.C., K. Ruiz de Luzuriaga, D.A. Wagner, W. Rand, N. Isfan, V.R. Young, and S.R. Tanneenbaum. 1981. Nitrate biosynthesis in man. Proc. Natl. Acad. Sci. USA 78:7764-7768.
Grosse, Y., R. Baan, K. Straif, B. Secretan, F. El Ghissassi, and V. Cogliano. 2006. Carcinogenicity of nitrate, nitrite, and cyanobacterial peptide toxins. Lancet Oncol. 7:628-629.

Hegesh, E., and J. Shiloah. 1982. Blood nitrates and infantile methaemoglobinaemia. Clin. Chim. Acta 125:107-125.

James, C., J. Fisher, V. Russel, S. Collings, and B. Moss. 2005. Nitrate availability and hydrophyte species richness in shallow lakes. Freshwater Biol. 50:1049-1063.

Kawanishi, S., Y. Hiraku, S. Pinlaor, and N. Ma. 2006. Oxidative and nitrative DNA damage in animals and patients with inflammatory diseases in relation to inflammation-related carcinogenesis. Biol. Chem. 387:365-372.

Larsen, FJ., B. Ekblom, K. Sahlin, J.O. Lundberg, and E. Weitzberg. 2006. Effects of dietary nitrate on blood pressure in healthy volunteers. N. Engl. J. Med. 355:2792-2793.

L'hirondel, J.-L., A.A. Avery, and T. Addiscott. 2006. Dietary nitrate: Where is the risk? Environ. Health Perspect. 114:A458-459.

L'hirondel, J., and J.L. L'hirondel. 2002. Nitrate and man: Toxic, harmless, or beneficial? CABI Publ., Wallingford, Oxfordshire, UK.

Lundberg, J.O., E. Weitzberg, J.A. Cole, and N. Benjamin. 2004. OpinionNitrate, bacteria and human health. Nat. Rev. Microbiol. 2:593-602.

National Academy of Sciences. 1981. The health effects of nitrate, nitrite and Nnitroso compounds. Committee on Nitrite and Alternative Curing Agents in Food. Part 1. National Academy Press, Washington, DC.

National Research Council. 1995. Nitrate and nitrite in drinking water. National Research Council. Subcommittee on Nitrate and Nitrite in Drinking Water. National Academy Press, Washington, DC.

Nishino, H., M. Murakoshi, W.Y. Mou, S. Wada, M. Msuda, Y. Ohsaka, Y. Satomi, and K. Jinno. 2005. Cancer prevention by phytochemicals. Oncology 69:38-40 (suppl.).

Pocock, S.J., A.G. Shaper, D.G. Cook, R.F. Packham, R.F. Lacey, P. Powell, and P.F. Russell. 1980. British regional heath study - Geographic variations in cardiovascular mortality, and the role of water quality. BMJ 280:1243-1249.

Potter, J.D., and K. Steinmetz. 1996. Vegetables, fruit, and phytoestrogens as preventive agents. IARC Sci. Publ. 139:61-90.

Rabalais, N.N., R.E. Turner, and W.J. Wiseman. 2001. Hypoxia in the Gulf of Mexico. J. Environ. Qual. 30:320-329.

Richardson, G., S.L. Hicks, S. O’Byrne, M.T. Frost, K. Moore, N. Benjamin, and G.M. Mcknight. 2002. The ingestion of inorganic nitrate increases gastric $S$-nitrosothiol levels and inhibits platelet function in humans. Nitric Oxide 7:24-29.

Sawa, T., and H. Oshima. 2006. Nitrative DNA damage in inflammation and its possible role in carcinogenesis. Nitric Oxide 14:91-100.

Sharpley, A.N., S.C. Shapra, R. Wedepohl, J.T. Sims, T.C. Daniel, and K.R. Reddy. 1994. Managing agricultural phosphorus for protection of surface waters: Issues and options. J. Environ. Qual. 23:437-451.

Shuval, H.I., and N. Gruener. 1977. Health effects of nitrates in water. Report EPA-6000/1-77-030. USEPA, Cincinnati, OH.

Turner, R.E., and N.N. Rabalais. 2003. Linking landscape and water quality in the Mississippi River basin for 200 years. Bioscience 53:563-572.

Van Grinsven, H.J.M., M.H. Ward, N. Benjamin, and T.M.C.M. de Kok. 2006. Does the evidence about health risks associated with nitrate ingestion warrant an increase of the nitrate standard for drinking water? Environ. Health 5:26 doi:10.1186/1476-069X-5-26.

Van Loon, A.J., A.A. Botterweck, R.A. Goldbohm, H.A. Brants, J.D. van Klaveren, and P.A. van den Brandt. 1998. Intake of nitrate and nitrite and the risk of gastric cancer: A prospective cohort study. British J. Cancer 78:129-135.

Vermeer, I.T.M., D.M.F.A. Pachen, J.W. Dallinga, J.C.S. Kleinjans, and J.M.S. van Maanen. 1998. Volatile N-nitrosamine formation after intake of nitrate at the ADI level in combination with an amine-rich diet. Environ. Health Perspect. 106:459-463.

Ward, M.H., T.M. de Kok, P. Levallois, J. Brender, G. Gulis, B.T. Nolan, and J. VanDerslice. 2005. Workgroup report: Drinking water nitrate and health—Recent findings and research needs. Environ. Health Perspect. 113:1607-1614.

Ward, M.H., T.M. de Kok, P. Levallois, J. Brender, G. Gulis, J. VanDerslice, and B.T. Nolan. 2006. Respond to dietary nitrate: Where is the risk? Environ. Health Perspect. 114:A459-A460.

World Health Organization. 2004. Recommendations; nitrate and nitrite. p. 417-420. In Guidelines for drinking-water quality, 3rd ed. WHO, Geneva, Switzerland.

Ying, L., and L.J. Hofseth. 2007. An emerging role for endothelial nitric oxide synthase in chronic inflammation and cancer. Cancer Res. 67:1407-1410. 